\title{
PReS13-SPK-1590: Relevance of cytokine in pediatric inflammatory disease
}

\author{
F De Benedetti \\ From 20th Pediatric Rheumatology European Society (PReS) Congress \\ Ljubljana, Slovenia. 25-29 September 2013
}

Cytokines are pleiotropic mediators that play a major role in inducing and orchestrating the inflammatory and the immune response. They play a major role in the response to damage or infections. In some pathological condition abnormal regulation of the production of cytokines leads to pathological events and subsequent damage to target tissues. Dissecting the role of each single mediator in the plethora of cytokines and in the complex networks has been one of the aims of biomedical research that has led to relevant applications in rheumatic diseases. In the presentation we will briefly review the evidence leading to the identification of the role of some cytokines (IL-1, IL-6 and TNF) as key mediators and therapeutic targets in pediatric rheumatic diseases.

\section{Disclosure of interest}

None declared.

Published: 5 December 2013

Submit your next manuscript to BioMed Central and take full advantage of:

- Convenient online submission

- Thorough peer review

- No space constraints or color figure charges

- Immediate publication on acceptance

- Inclusion in PubMed, CAS, Scopus and Google Scholar

- Research which is freely available for redistribution 